\title{
O DIVORCI0
}

Não comprehendo como possa haver quem seja contra o divorcio a vinculo.

O divorcio deve ser facil, rapido, simples e sempre prompto a attender ao desejos das partes.

O desquite do nosso Codigo, tendo a seu lado a annullação do casamento, é pratica immoral e contraria ao espirito da nossa época.

\section{O CASAMENTO E A FAMILIA}

O casamento é um simples contracto, e deve ser distratavel como qualquer outro.

Não posso conceber que duas pessoas se unam perpetuamente pelo casamento, pois tudo no mundo é varùavel e mutavel, inclusivé os sentimentos.

Dizem que a familia, pedra angular da sociedade, basela-se no casamento: - seja .

Mas, todos concordarão commigo em que póde haver sociedade com a polygamia e em que o casamento monógamo não é portanto de imprescindivel necessidade para que exista familia e sociedade bem organizada, e mesmo, altamente moralizada.

Serão mais moralizadas as sociedades christãs do que aquellas em que existe a polygamia?

Demäis, a moral é exclusivamente convencional.

Cesse portanto o temor de modificar-se a organização da familia: - esta passou por uma evolução, transformou-se completamente

Devemos é observar os factos e reconhecer o que se passa nạ réalidade, pois as leis que não se baseam na consciencia popular nunca serão respeitadas. 


\section{O DIVORCIO}

A nossa situação actual é contraria á moral e aos* principios democraticos.

Temos para os ricos e poderosos o divorcio a vinculo, por meio da annullação de casamento; para o commum dos mortaes, apenas o absurdo do desquite do nosso Codigo. ticos?

Não é um ataque tremendo aos principios democra-

\section{IMMORALIDADE E ABSURDO}

O casamento perpetuo é, quasi sempre, immoral e absurdo. Haverá maior infamia, mais formidavel indecencia do que a cohabitação de duas pessoas que se aborrecem cordialmente? Haverá maior sacrificio do que o que faz a mulher que vive com um marido de que não gosta?

A sua posição é mais degradante do que a da prostituta: - esta entrega-se a homens que lhe são indifferentes parai ganhar a vida, aquella supporta um homem que aborrece devido á escravidão lègal a que ainda está sujeita a mulher nesta época de civilização e liberdade.

Responderão os adversarios do divorcio: - a mulher tem remedio na lei.

Mentira! A lei é hypocrita e absurda.

A lei protege os ricos e poderosos, como disse acima, dandio-lhes a annullação do casamento. Mas, qual a posição do pobre, do vulgo?

Este tem o simples desquite que nada adeanta, como vou provar. De duas uma: ou ha culpa na desharmonia do casal, ou nenhum dos conjuges é culpado, ha apenas differenças de genios ou de temperamento. 


\section{QUANDO UM DOS CONJUGES É CULPADO}

Quando, por exemplo, a mulher é adultera, é má e o marido é optima creatura, terá este o direito de levar a cabo o nosso processo escandaloso de desquite, infamando a mãe de seus filhos, creanças innocentes e puras, que outra culpa não têm sinão a de serem filhos de uma mulher de maus sentimentos?

Haverá uma bôa mãe que não prefira o martyrio de supportar um marido bebado e crapuloso a desmoralizar o pae de seus filhinhos?

Será sempre, mesmo em face dos principios mais rigorosos de uma moral purissima, condemnavel e imperdoavel o adulterio?

\section{QUANDO NENHUM DOS CONJUGES É CULPADO}

Ha numerosos casos em que ambos os conjuges são bôas pessoas mas ha absoluta impossibilidade de vida em commum, por divergencia de genios ou de temperamento.

Será justo que os infelizes sejam sacrificados pela sociedade porque antes do casamento não adivinharam os respectivos genios?

Separem-se dirão.

E depois? Não podendo casar-se novamente terão que contrahir fatalmente ligações livres: - eis a sociedade auxiliando a prostituição.

\section{A SOLUÇÃOO}

Proponho a seguinte solução: - o divorcio deve ser concedido immediatamente, desde que um dos conjuges manifeste o seu desejo de não mais continuar o casamento. Deve, além disso, ser prohibido expressamente dar os motivos do divorcio. Devemos encarar no casa- 
mento sómente o interesse dos filhos: - é a unica missão da sociedade. $O$ contracto de casamento deve ser um contracto de proteç̧ão á prole. E' esta a unica solução racional e compativel com a nossa civilização.

\section{A DISSOLUÇÃO DA SOGIEDADE}

Chamarão os tartufos que quero a dissolução da sociedade: - é falso! Quero é a liberdade da mulher, a egualdade dos sexos, o progresso, a paz e a felicidade geral.

E Deus?.. Será a pergunta dos crentes. Haverá alguem que pense em Deus em assumpto tão humano e positivo?

Deixemos de methaphysica e hypocrisia:- reconheçamos a realidade e com ella o divorcio simples, rapido, sem nenhum obstaculo.

São Paulo, 1927.

Braz de Sousa Arruda. 